As manifestações expressas por integrantes dos quadros da Fundação Getulio Vargas, nas quais constem a sua identificação como tais, em artigos e entrevistas publicados nos meios de comunicação em geral, representam exclusivamente as opiniões dos seus autores e não, necessariamente, a posição institucional da FGV. Portaria FGV No 19

Escola de Economia de São Paulo da Fundação Getulio Vargas FGV EESP www.fgv.brleesp 


\title{
Neutralizing the Dutch Disease
}

\author{
Luiz Carlos Bresser-Pereira
}

\begin{abstract}
This paper discusses the political economy involved in the required neutralization of the Dutch disease - a long-term overvaluation of a national currency originated in exports of commodities that generate Ricardian rents or benefit from commodity booms. The difficulty in dealing with this market failure is associated to two political problems: the natural resource curse, which is the generalized rent-seeking that often takes over a commodity-exporting country, and exchange rate populism, the practice of keeping the currency overvalued, to ensure the reelection of politicians. While the two political problems have cultural and institutional roots that make them resilient to change, this paper shows that there is a relatively simple policy that will effectively turn the currency competitive and the manufacturing industry, a possibility.
\end{abstract}

Key words: Dutch disease, natural resource curse, exchange rate populism, new developmentalism.

To industrialize and make the catching up, developing countries must overcome or neutralize a major economic disadvantage confronting most of them: the Dutch disease - a long-term overvaluation of the currency of a country that exports commodities which can be exported at a profit with an exchange rate substantially more overvalued than the one that the manufacturing industry companies utilizing technology in the world state of the art require to be profitable. The development economics literature associates economic growth with education, good institutions, the emulation of technology of rich countries, and the protection of the manufacturing industry. Today the last item is harshly criticized by most economists, who only accept high import tariffs when industrialization is beginning and the infant industry argument is valid. Yet, as I will argue in this paper, many countries that industrialized used successfully high import tariffs, not to protect the manufacturing industry, but to neutralize the Dutch disease on the domestic market side, and, so, leveling the playing field.

Although many countries have neutralized the Dutch disease with import tariffs, they are not the best way to neutralize the disease because they only do that in relation to the domestic market; policymakers had to act intuitively and pragmatically, without knowing precisely what they were doing, because the concept and the methods for neutralizing the disease were yet known. The import substitution strategy that many countries adopted to industrialize was a method of neutralizing a major economic disadvantage, the disease, rather than a form of protectionism. It is true that the policy could be combining the two things (leveling the playing field and, in addition, protecting), whenever the tariffs exceeded what was required to check the disease. In a big domestic market, such as Brazil, the country may industrialize based on import tariffs; in a very big domestic market, as the United States, the country may become rich. This may seem surprising in relation to the US, but the simple facts are, first, that it was afflicted by the disease initially due to the exports of cotton and wheat, and later the exports of oil; second, it kept tariffs high on manufactured goods long after outgrowing the infant industry

Luiz Carlos Bresser-Pereira is emeritus professor of the Getúlio Vargas Foundation. 
stage, not opening its economy until 1939! There is little doubt that the American policymakers were intuitively neutralizing the Dutch disease. ${ }^{1}$

In this paper, I will discuss the role played by the Dutch disease in the determination of the exchange rate, its definition, how it must be distinguished from the natural resource curse, and how it can be neutralized, using as reference the new developmental economics (NDE) that a group of post-Keynesian and developmental economists in Latin America, including myself, have been developing since the early 2000s. ${ }^{2}$ I start from two assumptions: that growth involves industrialization or competitive sophistication, and that the growth depends on the rate of investment. There are other variables on the supply side besides capital accumulation that cause growth, such as education, technical progress, good institutions, investments in the infrastructure and a stable national currency, and on the demand side we know how important it is to have sustained demand, but investment in physical capital is the most significant factor, Technical progress is mainly embodied in physical and human capital. Education and institutions are very important, but they don't make a difference in the short-term. These variables assure a return on investment, but this is difficult to measure and only emerges over the long-term. Institutions are mostly celebrated, particularly those that guarantee property rights and contracts, but they form an endogenous variable that is simultaneously a cause and a consequence of growth. In contrast, the investment rate - of public investment (mainly infrastructure) and of private investment (in all other sectors of the economy) - operates simultaneously on both the supply and demand sides, and has a direct relation to growth.

To the two assumptions I add a claim: that the investment rate depends inversely on the exchange rate: when the currency is overvalued cyclically for long periods (not merely volatile), investment in the tradable non-commodity industries will go down. In that case, a country's competent manufacturing industries cannot become competitive. But under what conditions would the currency be overvalued or the exchange rate high in the long-term? Because, in developing countries there is a tendency toward the cyclical and chronic overvaluation of the national currency. As I have been arguing for several years, in the theoretical framework of new developmentalism, the exchange rate is not just volatile. Contrary to claims made by other theories, it doesn't just oscillate rapidly around the equilibrium. Instead, it remains substantially overvalued in each cycle, which has a duration of several years. At the start of a financial crisis - usually a currency crisis - the exchange rate depreciates sharply. Once it reaches a peak it starts falling (appreciating) gradually, reaches a kind of floor and remains on or near this floor for some years, probably reflecting the lowest exchange rate that the more efficient commodity exporters can tolerate. Why is the behavior so cyclical? There are two reasons: because the country utilizes high interest rates to attract foreign capital and because it suffers from Dutch disease that has not been neutralized.

Thus, when a company sees demand satisfying domestically or abroad and considers a new investment, it will probably calculate its likely return in light of the overvalued currency and, most likely, will either not invest at all or will invest just enough modernize the plant, but not enough to expand production. When the exchange rate is volatile, business decision-makers are insecure; when the exchange rate is overvalued in the long-term, they will decline to invest. The exchange rate acts as a switch that grants or withholds access to existing demand, be it international or domestic.

\section{The disease and the curse}

There are two very different concepts that have a similar origin and represent major obstacles to growth in developing countries: the Dutch disease and the natural resource curse. 
The natural resource curse is essentially a political-institutional problem; it is the generalized rent-seeking that occurs in a country exporting commodities; it is the transformation of the state into a predator or an extractive state in which the government and the economic and political elites are oriented not to production, but to the capture of rents by imposing a tax on the export of the commodities. In contrast, the Dutch disease is an economic problem, it is a competitive disadvantage that blocks industrialization. If the country is already industrialized, it causes premature deindustrialization. Both the natural resource curse and the Dutch disease arise because such commodities benefit from Ricardian rents and/or from commodity booms, but their nature and consequences are different. The curse involves the demoralization of politicians and businessmen and the immobilization of the state. The Dutch disease blocks industrialization or, more broadly, the productive sophistication of the country, and condemns it to eternally being an exporter of commodities.

The literature on the Dutch disease is scarce. Yet, in 2007, an interesting book was published: Escaping the Resource Curse, edited by Macartan Humphreys, Jeffrey D. Sachs and Joseph Stiglitz, with a preface of George Soros. ${ }^{3}$ Its editors acknowledge that the natural resource curse and the Dutch disease are serious problems, but ultimately, they emphasize the political-institutional problem, the natural resource curse. This is possibly because the three distinguished economists were unsatisfied with the economic solution that they offered for the disease. In his chapter, Sachs (2007: 191) prescribes certain economic policies designed to overcome the problem. His essential recommendation is that "oil earnings are invested in ways that enhance productivity, and thereby raise rather than lower production in the non-oil traded good sector". He also considers pegging the national currency to the dollar, but notes that pegging requires substantial foreign exchange reserves. And he gets near the solution of the problem when he considers the possibility of subsidizing the production of manufactured goods that make a significant contribution to improving the technological sophistication of the economy, but he does not explore this possibility. As we will discuss in a moment, there is a better solution to the long-term structural problem of the Dutch disease.

In his preface of this book, George Soros (2007: xi) remarks that both the curse and the disease involve three problems, namely currency appreciation (the disease), the wide fluctuation of commodity prices, and their effect on political conditions (the curse). And he asserts: "The first two are purely economic factors and have been studied extensively. It is the third factor that needs to be better understood." He is right in distinguishing the three problems; he is also right as to the difficulties posed by the natural resource curse, which is a cultural and institutional problem; but I believe that he underestimated economists' understanding of the Dutch disease, for which the three editors of the book and the academics they invited didn't offer a sensible or persuasive solution. If they knew what must be done, Soros would have espoused it vigorously, because he is a pragmatic economist and financier. He rightly understands that the curse is a difficult problem, because the rent-seeking if not the sheer corruption, which characterizes many countries engaged in exporting commodities, is a problem that defies simple solution. He would, however, had realized that for the disease there is a solution that is difficult, because involves distribution in the short-term, but is nonetheless a simple solution in economic terms.

This solution what I intend to make clear in this paper. I will show that there is a clear economic policy solution for the Dutch disease, which countries don't adopt not only for political reasons, but because policymakers are unaware of it. There is direct political problem - the opposition of workers and of rentier capitalists and financiers to the one time depreciation of the national currency that is required to achieve a competitive exchange rate. The economic solution, which I defined in my first paper on the Dutch disease (Bresser-Pereira 2008) remains 
essentially unknown. This paper is a new attempt to call attention to this solution, which addresses an enormously important problem for many developing countries.

The pragmatic and intuitive ways of neutralizing the Dutch disease were deployed between the 1930s and the 1970s, when the World Bank was the leading international agency adopting development economics or classical developmentalism, and rich countries adopted Keynesian, social-democratic and developmental policies. Yet, a shift began with the first oil shock (1973), and since 1980, the UK and the US, followed by the other rich countries, adopted for themselves a new neoliberal credo, reduced the policy space for developing countries, and started pressing them to adopt the same reforms and policies. Consequently, countries engaged in reforms which blocked or, in the case of Brazil, dismantled the pragmatic system that was neutralizing the disease.

There is today a large literature on the "middle-income trap" that countries like Brazil have been facing since the 1990s. Indeed, many nations, for sure, Brazil, have been caught in a trap. Since 1990 the Brazilian economy has being growing at an yearly income per capita rate four times smaller than the one prevailing between 1950 and 1980. But the main cause of such quasi-stagnation was not the lack of good institutions, as this literature has suggested. The institutions didn't suddenly deteriorate. The trap was created by the dismantling of the mechanism that neutralized the disease, which was embodied in Brazilian trade system. With the 1990 trade liberalization, the import tariffs and the export subsidies, which did not represent protectionism, but were aimed at leveling the playing field, were dismantled, this meaning that since then the manufacturing industry in Brazil, national or multinational, face a major competitive disadvantage in relation to the other countries.

\section{The Dutch disease in NDE}

The Dutch disease is a long-term overvaluation of the currency resulting from exports of commodities which benefit from Ricardian rents or from commodity booms, and, therefore, can be profitably exported at an exchange rate substantially higher than the rate that manufacturing companies utilizing state-of-the-art technology can tolerate and remain competitive or profitable. The Ricardian rents are at the heart of the disease: I am assuming the price of the commodity is largely determined by the average cost of production in the least efficient country that is admitted to the market. Given this cost, the countries that have a lower cost of production than the international price will capture the corresponding differential rents. Among the producers of each country we will have the more and the less efficient, but for the concept of the Dutch disease it is the cost of the country - the average cost of the companies that is relevant.

The first economist to grasp the dynamics of the Dutch disease was Marcelo Diamand. This distinguished Argentinean economist realized the overvaluation of the peso, which was originated from the exports of wheat, soy beans and meat. At his time, the expression "Dutch disease" had not yet been coined, but he defined the countries like Argentina, which faced it, "unbalanced productive structures" - economies in which, following Dvoskin and Feldelman (201\%: 221), two or more sectors operate under considerably different levels of productivity... which cannot be eliminated by standard devaluations of the exchange rate". In a 1972 paper, he offered the explanation of the problem. Taking South Korea, the US and Italy as reference points, he argued that:

In each of the countries, the exchange rate is precisely at a level necessary for the price of industrial products to be translated into dollars equal to the international price... In Argentina, the fact that the exchange rate is fixed on the basis of the most productive sector becomes the 
central determinant of the lack of industrial exports and starts the chain of events that culminates with the crisis and the Argentine stagnation. (Diamand 1972: 9-10)

In other words, as the commodity sector in Argentina exported, that raised the value of the host currency to a point where the investments und consideration or potentially under consideration in the tradable non-commodity industries would not be profitable, and would not be transformed into reality.

The first two economists to offer a model of the Dutch disease were Corden and Neary (1982). Our 2008 model was the second one to define the disease in theoretical terms. The two models have in common the three sectors in which the economy is divided (a commodity exporting sector, a non-commodity tradable sector and a non-tradable sector) and the fact that the overvaluation applies to the tradable non-commodity sector. Meaning, in practical terms, that it is manufacturing which suffers from the overvaluation and turns non-competitive. Our descriptions differ because the Corden and Neary's model limits the disease to commodity booms, while the new-developmental model adds a more long-term factor: the differential or Ricardian rents, which, considering competition, will be higher or lower depending on the cost of production of the last less efficient producer admitted in the market and the cost of production of the other countries, and, considering monopoly power, the additional rents that derive from the variation of the international the price of the commodities above the cost of production of the less efficient producer. The models also differ because the newdevelopmental model uses two equilibrium exchange rates, and because it can derive the policy that will neutralize the disease directly from those rates. More generally, the two models differ because one stems from neoclassical economics, while the other from classical economics; the determination of the price in neoclassical theory depends only on the demand and supply of the good or service, while in classical theory it fluctuates according to the supply and the demand around its value or production cost.

Although the Dutch disease is a major competitive disadvantage for any country exporting commodities and a major reason that hampers industrialization in developing countries, it has received little attention from economists. Instead, they have been attracted to the political problem, the rent-seeking involved in the "natural resource curse". This is indeed a serious problem in countries where the culture and the institutions aren't modern, i.e., aren't propitious to investment, technical progress and growth. But there is no simple solution for this problem, in so far as culture and institutions are endogenous to the process of economic development.

\section{Determination of the exchange rate}

In the new-developmental economics, the Dutch disease is one factor determining the exchange rate. I will now summarize this determination, because comprehending it makes it easier to understand the policies that will neutralize it. In determining the exchange rate, we must start from the value of the foreign money, around which the exchange rate floats according to the supply and demand for foreign money. This value is value that covers the cost of production of the goods and services exported that balance the current account of the country. It varies according to the variation of comparative unit labor cost of this country; if the unit labor cost of the country, i.e., the wages divided by the productivity of labor, increase more in this country than in its competitors, the value of the foreign currency goes up and pushes the exchange rate to depreciates to keep the current account balanced.

To define the Dutch disease, instead of focusing on the value of the foreign money, we need the current equilibrium - the exchange rate that balances intertemporally the current account 
of the country - and the industrial equilibrium. The current equilibrium is dependent on the value of the foreign money and on the international price of the commodities exported. The industrial equilibrium is the exchange rate that the companies producing manufacturing goods (or, more generally, tradable non-commodity goods and services) utilizing state-of-the-art technology require to be competitive. The Dutch disease can be defined as the difference between the two equilibriums. Economics assumes that the industrial equilibrium should be equal to the current equilibrium. As they are not equal in many countries, the Dutch disease represents a major market failure, or, to look at it from a different angle, a major competitive disadvantage. It turns all companies producing non-commodity tradable goods and services non-competitive. This is true for both existing companies and for potential ones.

Thus, first, the exchange rate is determined by the value of the foreign currency, which, in its turn, depends on the comparative unit labor cost of the country, and, second, the exchange rate depends on the supply and demand for foreign money, which makes the exchange rate float around the value. The next problem in the determination of the exchange rate is to know how the supply and demand for foreign money works. Does the supply and demand make the exchange rate to follow a certain pattern? Or is it heavily influenced by unpredictable capital flows, as many believe, given that capital flows have increased strongly in the modern capitalist era. NDE opts for the first explanation. The capital flows depend mainly on the interest rate, which, in turn, tends to be set at a level high enough to attract capital and to serve as a nominal anchor against inflation. Thus, despite the magnitude of the capital flows, the exchange rate follows a pattern: the tendency to move to a cyclical and long-term chronic overvaluation of the exchange rate, which is depicted in Figure 1 with the two equilibriums. Currency crises mark the end and the beginning of each cycle. When a country is hit by a financial crisis, the national currency devalues sharply, and often moves well above the industrial equilibrium. Once the crisis abates, the currency begins to appreciate again, crosses the industrial equilibrium and then the current equilibrium, enters the realm of current-account deficits, and eventually reaches a floor where it remains for several years. Given the overvalued currency, the current-account deficit increases dangerously and the foreign debt rises to a point at which international creditors suddenly lose confidence and stop the roll-over of foreign debt, and a new currency crisis breaks.

Figure 1: The exchange rate and the two equilibriums

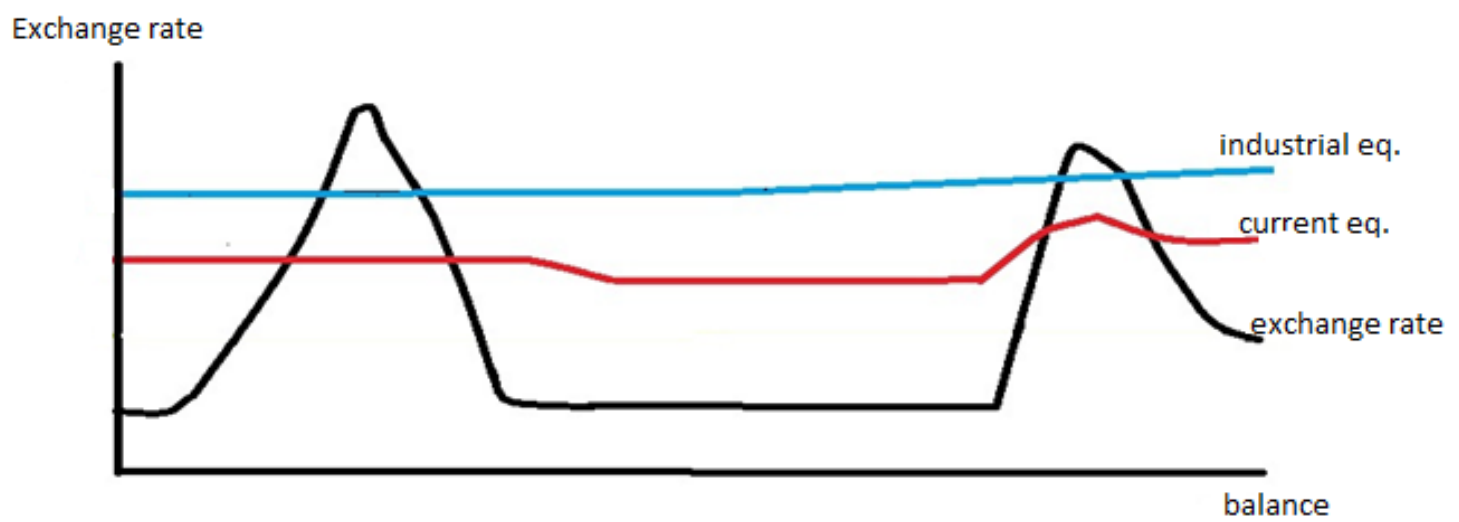

In this cyclical process, two factors cause such an appreciation after the financial crisis: the Dutch disease, which pulls the exchange rate up to the current equilibrium, and the interest rate which, when set at a high level in relation to the international interest rate, attracts foreign capital and makes the country to experience a mounting current account deficit. As the financial 
crisis retreats, the currency gradually appreciates again, pulled up, first, by the Dutch disease, up to the current equilibrium, which is determined by the commodities. To continue to appreciate and cross the current equilibrium the exchange rate must now be pulled up by a high interest rate level. ${ }^{4}$ Why do developing countries often use high interest rates? To implement two habitual and usually equivocated policies: $(a)$ the policy of growth with current-account deficits and foreign indebtedness or with "foreign savings", and $(b)$ the use of the exchange rate as an anchor against inflation. They also pursue high interest rates for a reason of political economy: the power of rentiers and financiers to obtain high interests.

\section{Figure 2: Current-account and exchange rate}

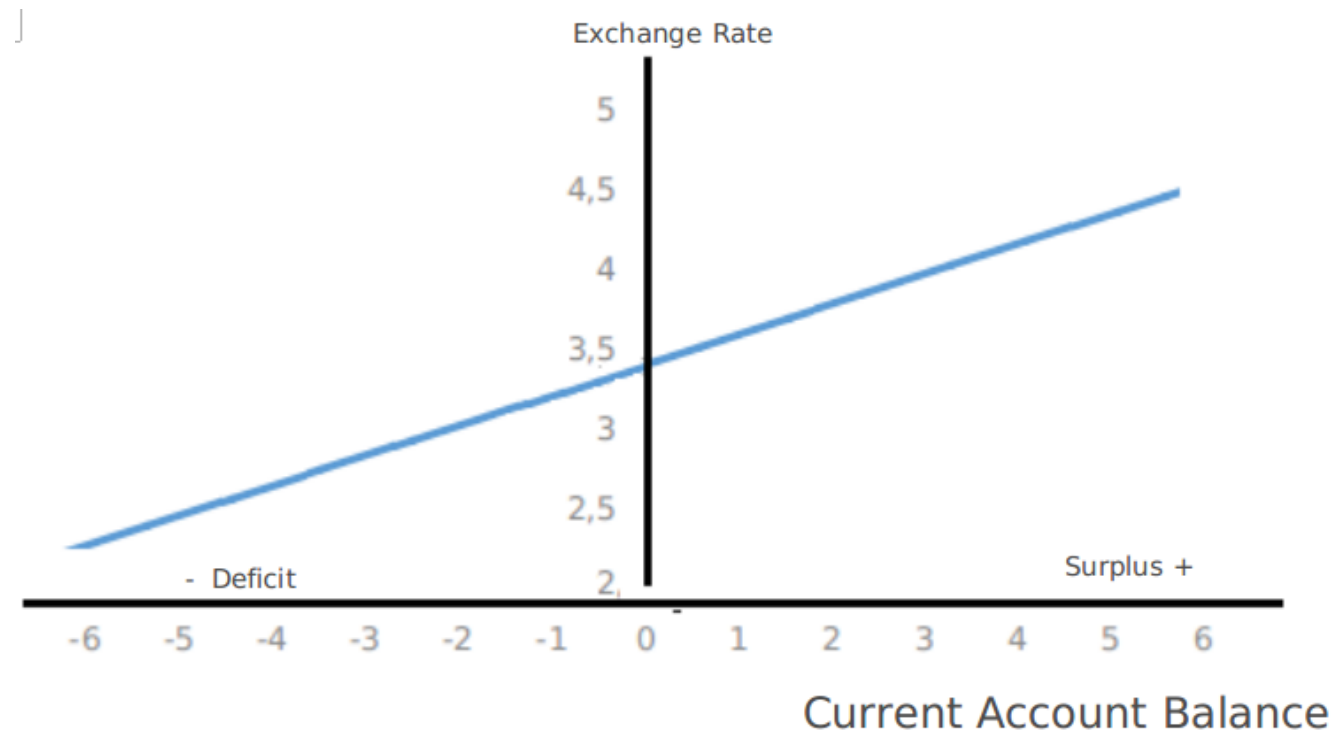

Summarizing, the exchange rate is, firs, determined by the value of the foreign currency; second, it floats around this value, according to the supply and demand of foreign money, follows a cyclical process. In this process, the exchange rate remains on a kind of bottom for several years, during which it cannot appreciate because below this level even the commodities will turn not-competitive, making a loss. To remain at this bottom while the exchange rate regime is a floating regime, a credit bubble necessarily materializes. This will happen because creditors are happy with the high interest rate, and the multinationals are happy with their sales and profits. Yet, sooner or later the creditors will lose confidence, and this bubble will burst. In this model, the capital flows have a role, but they follow the pattern just described. The exchange rate volatility has a direction and follows a pattern. ${ }^{5}$

The theory on the determination of the exchange rate just summarized here considers flows: flows of imports and exports, and of capital. But we can also think in terms of a stock which involves flows: the current-account balance. With other variables constant, there is a simple correspondence between the current-account balance and the exchange rate, which is depicted in Figure 2. The exchange rate that balances the current account is substantially more competitive than the exchange rate that balances a current-account deficit of, for instance, $3 \%$ of GDP. This is usually disregarded by economists, because the current-account balance is viewed as the dependent variable, and the variations in the exchange rate regarded as the independent one. This is what usually happen: some exogenous factor appreciates or depreciates the exchange rate and current account changes accordingly. Yet, thinking in a longer term, this is not the reality for developing countries. Their policymakers believe they should grow by borrowing foreign money, because the corresponding "foreign savings" (the 
current-account deficit) would add to the domestic savings, and the rate of investment would increase. Thus, their policymakers decide to incur current-account in a permanent deficits, whose only constraint is keeping the country's rate of foreign indebtedness constant. They don't consider that this deficit will hnave to be permanently financed by capital inflows which will appreciate the national currency and make the tradable non-commodity local companies uncompetitive. They ignore that such usual policy encourages consumption while discouraging investment.

How does this corresponding relationship between the current-account balance and the exchange rate create the appreciation of the national currency? Simply by the permanent increase of capital inflows that are required to finance the current-account deficit. The currentaccount deficit becomes "normal", or "structural", thereby causing the permanent overvaluation of the national currency.

Figures 1 and 2 illustrate the new-developmental model of what determines the exchange rate. Figure 1 shows the cyclical behavior of the exchange rate and the behavior of the current and industrial equilibriums. We have the two value equilibriums and the exchange rate. The industrial equilibrium and the current equilibrium vary over time: the industrial equilibrium fluctuates mainly because of changes in comparative unit labor costs, the current equilibrium mainly because of variations in the terms of trade. The exchange rate follows the tendency to a cyclical and chronic overvaluation of the currency. Figure 2 shows the linear, timeindependent, relation between the current account and the exchange rate, which turns into a determinant of the exchange rate once policymakers choose to pursue economic growth using net foreign indebtedness.

The recent Brazilian cycle, which lasted from the 2002 until the 2014 financial crises, is a good example of the theory. In the third quarter of 2016, the industrial equilibrium increased from $\mathrm{R} \$ 3.80$ to $\mathrm{R} \$ 4.00$ per dollar because of the rise in comparative unit labors cost in Brazil; the current equilibrium fluctuated around R \$ 3.20 per dollar from 2007 to 2013, meaning that the Dutch disease inflated the currency by between $\mathrm{R} \$ 0.60$ and $\mathrm{R} \$ 0.80$ per dollar, while the exchange rate floated around the bottom line at $\mathrm{R} \$ 2.80$ per dollar, causing an average currentaccount deficit of $3 \%$ of GDP. As a consequence, in this period the country experienced a new wave of deindustrialization, as the profit rate of the manufacturing companies fell dramatically and they became highly indebted. In 2014, a major fall in the country's export commodities' prices triggered the decision by the companies to stop investing, and a major recession unfolded.

\section{Neutralization of the Dutch disease}

The Dutch disease is a problem as old as capitalism and international trade. It is a major problem that will change how economic history is understood once it is considered by economists and historians. I understand that the main cause of the decline of Spain and Portugal from the sixteenth century was the Dutch disease that stemmed from the gold, silver, and sugar cane that these countries obtained from their colonies. Their currencies remained overvalued in the long-term, making industrialization and growth unviable. The neutralization of the Dutch disease is also an old practice, although the disease was only defined in the 1980s, and the correct way of neutralizing it, only in the late 2000s. This fact didn't stop pragmatic and competent policymakers from searching for ways to neutralize it and, in many cases, achieving a positive outcome intuitively. Yet, in most cases, such intuitive neutralization was only achieved in relation to the domestic market of the country, not in relation to the foreign markets. The usual policy adopted was to impose a high import tariff on the manufactured imported 
goods. A $20 \%$ tariff, for example, is equivalent to depreciating the currency by $20 \%$, The tariff establishes a dual, if not a multiple, exchange rate regime. Some countries adopted directly dual or multiple exchange rate regimes instead of tariffs.

Liberal economists indicted import tariffs as "protectionism" and developmental economists defended it in the manner of Alexander Hamilton, with the infant industry argument. Besides the infant industry argument, the neutralization of the Dutch disease also justifies import tariffs, which, in this case, don't configure protectionism; the import tariff is merely leveling the playing field.

Import tariffs are usually viewed either as justified by the infant industry argument, or viewed as protectionism. Now, confronting import tariffs, there is a third alternative: they may be a tool for neutralizing the Dutch disease on the domestic market side. And we have a new explanation for the import substitution model of industrialization. If the disease was not present, and depending on the size of the domestic market, the industrialization would take place without the protection of tariffs; the industrial companies would be taking advantage of proximity either in terms of transport costs, or in terms of adjustment to the demand. As the countries faced the disease, they had no alternative but to impose the tariffs to industrialize.

In countries that adopted the import substitution strategy, growth rates fell once the domestic market was saturated: it fell sooner or later depending on the size of the domestic market. The import tariffs on manufactured goods neutralized the disease only in the domestic market. If the neutralization of the disease was also done in relation to the foreign markets, this constraint would not be constraint to further growth. The small countries could specialize in exporting in a few industries. This was what a large country, Brazil, realized when, in 1967, it completed its intuitive neutralization of the Dutch disease by adopting a major program of subsidizing exports of manufactured goods. The average import tariff at the time was very high: $45 \%$. The export subsidy was equally high: $45 \%$. Besides neutralizing the disease, the tariffs also had a protectionist character. The policy was highly successful. Exports of manufactured goods represented only $6 \%$ of total exports in 1965 ; by 1990 , they had reached a peak of $62 \%$. Yet, in that year, weakened by ten years of foreign debt crisis and high inflation, the country agreed to liberalize trade, believing that it was only eliminating protectionism. What it didn't realize was that in fact, it was dismantling the mechanism that had neutralized the Dutch disease. From then on, the country faced major deindustrialization and low growth rates.

The use of high import tariffs and export subsidies on manufactured goods or multiple exchange-rate regimes is not the best policy to neutralize the Dutch disease. The most effective form is the imposition of a variable tax or retention on the exports of the commodities that generate the disease. If, at a given point, the industrial equilibrium is $\mathrm{M} \$ 4.00$ and the current equilibrium, M\$ 3.20 per dollar, the tax would be $\mathrm{M} \$ 0.80$ per dollar ( $\mathrm{M}$ being the national currency). The tax - which is the difference between the industrial equilibrium and the current equilibrium - varies according to the severity of the disease, which depends mainly on the variation in the commodities' international prices. That is, when the prices increase, the disease turns more severe and the tax required to cure the disease must also increase, and vice versa. The definition of the tax should not be at the discretion of the finance minister, but should be set in law, which will have for each relevant commodity a table associating price intervals with the respective tax, with both values defined in real terms. The original construction of the table requires an estimation of the industrial and the current equilibrium. If the disease is not severe and the international price of the export commodity falls substantially, the tax may be set at zero. And we can even have a case in which the price falls so much that the tax turns into a temporary subsidy. Brazil's industrialization (1930-1980) was a result of the government 
adopting, over fifty years, several forms of multiple exchange rate regimes that neutralized the Dutch disease. They were a "disguised" export tax, which the coffee producers called "exchange rate confiscation". In short periods when the international price of coffee fell a great deal and its exports turned "gravoso", i.e., when the export price didn't cover the cost of production, the government was supposed to create a special fund to compensate the commodity exporters.

Why does the export tax neutralize the Dutch disease? Because it increases the cost of producing the commodity, and, as a consequence, always assuming a floating exchange rate, the current equilibrium will converge to the industrial equilibriums. Another way of explaining the same thing is to consider a principle taught in basic microeconomics: when a tax is imposed on the sale of a good, the supply curve of the commodity shifts to the left; given that the demand of the good is inelastic in relation to the country's exchange rate, the demand curve is vertical, and the current equilibrium will converge on the industrial equilibrium. Figure 3 shows the neutralization of the Dutch disease by means of a shift in the supply curve.

Figure 3: Neutralization of the Dutch disease from shifting supply curve

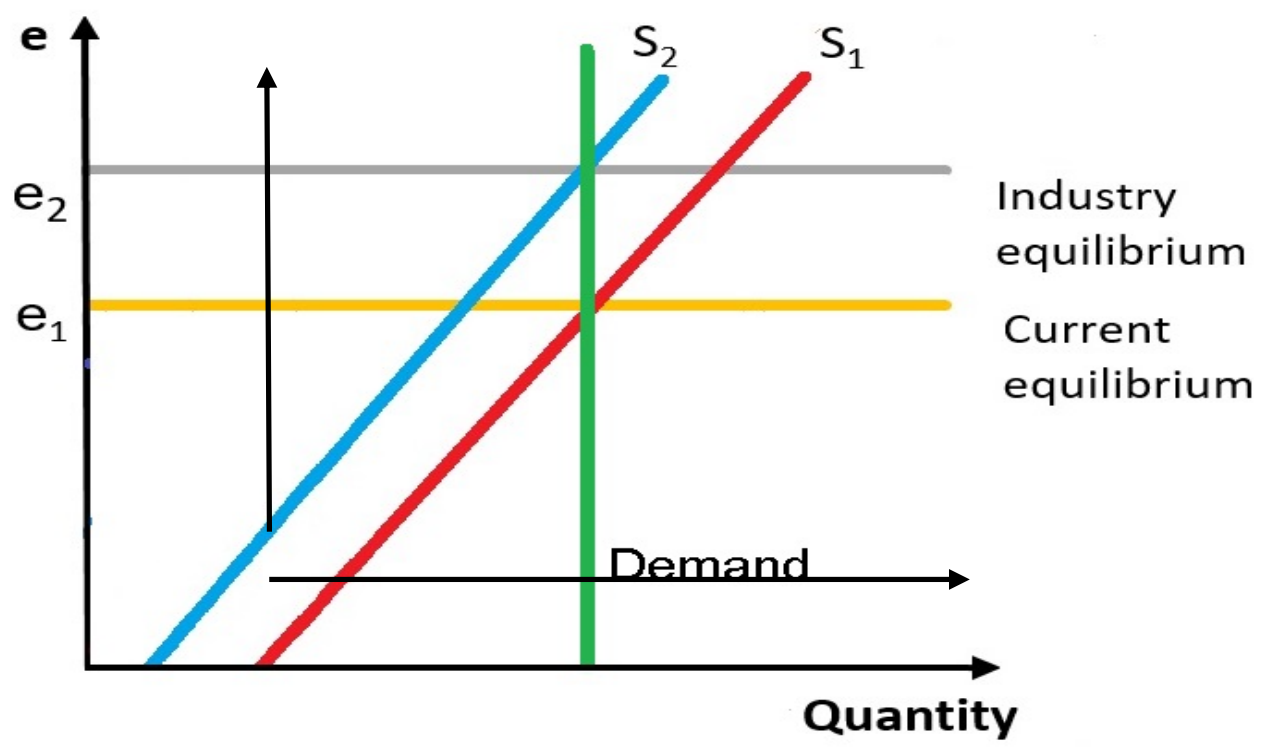

In our Brazilian example, an exchange rate of $\mathrm{R} \$ 0.80$ per dollar on the exports of the main commodities will neutralize the Dutch disease. In Argentina, in the major 2001 financial crisis, the government created a "retención" or on tax the export of commodities. It did so for fiscal reasons, not as a policy to neutralize the Dutch disease. Although it was a fixed tax, it did neutralize the disease, reindustrialization took pace, and high growth rates were achieved, while the country experienced a current account surplus. Then, in 2007, inflation increased. The government decided to use the exchange rate as an anchor against it, the current-account surplus evaporated, the peso appreciated, and the growth rate fell.

Note, however, that if the other basic cause of the long-term appreciation of the exchange rate is not also changed - if the interest rate is not reduced - the exchange rate will turn somewhat more competitive, but will remain uncompetitive.

What should be done with the new tax revenue? The only workable use is the creation of a sovereign fund, like Norway's fund. Contrary to a commonly held belief, the fund will not neutralize the disease (this is done by the export tax), but it will prevent hard currency inflows from re-appreciating the national currency, and, so is a necessary complement. As it is done in 
Norway, the fund will be fed by the tax, and only the revenues from the fund will enter the country. Without the fund and this policy, the tax will not work.

\section{Winners and losers}

Who will gain and who will lose when the disease is neutralized? The manufacturing industry will be the predicted and desired beneficiary; the good companies will turn competitive. The commodity exporters will pay the variable tax, but as this tax is equal to the disease, they will eventually spend nothing, because what they paid in taxes, they will get back in depreciation of the national currency. In the Brazilian case, they will pay $\mathrm{R} \$ 0.80$ per dollar exported, and receive $\mathrm{R} \$ 0.80$ back per dollar exported in the form of currency depreciation. The commodity producers will pay nothing in net terms, but they will lose the country rents, which will be captured by the state. Thus, we have two beneficiaries: the manufacturing industry and the state.

Who will pay? On one side, the wage workers and the salaried employees and managers, on the other, the rentiers, because the acquisitive power of the population will be reduced in the short-term by the depreciation. The rentiers will pay more than the workers and employees, because besides the fact that their revenues (interests, dividends and real-state rents) will lose purchasing power, their wealth will also lose value, and because the depreciation requires reducing interest rates - something that they oppose. This political economy problem explains why rentiers, the financiers who manage the wealth of rentiers, and the liberal economists who represent their interests, are not interested in discussing the exchange rate and the current account deficit; they are only interested in discussing the fiscal deficit. The same behavior on the part of the developmental economists who expect to represent the interests of workers is less understandable, because making the national currency competitive will mean more jobs for them almost immediately, and soon their wages will recover purchasing power.

Since the 1980s, economic populism was defined as the state irresponsibly spending more than it gets in taxes and incurs in chronic budget deficits. I call this "fiscal populism", to be distinguished from "exchange rate populism", where the nation-state is spending more than it gets and incurs in current-account deficits Exchange rate populism, which keeps the currency appreciated is very attractive to politicians who want to be re-elected. It increases the incomes of all (not only the wages of workers and the salaries of the middle class, but also the incomes of rentier capitalists in the form of interest, dividends and real-estate rents), and it makes everybody look richer. The fact that the neutralization of the Dutch disease involves a depreciation of the currency makes this policy unattractive both to politicians and to the people. This is one of the two reasons why it is difficult for countries to impose the required tax. The other reason is the natural resource curse.

Summing up, there is a solution to the Dutch disease, a simple solution. But it involves short-term costs, and, for that reason, faces political constraints. In contrast, there is no simple solution for the natural resource curse. The latter is a political and institutional problem with strong cultural roots. It tends to be overcome when the country industrializes, becomes capitalist, contractual, and democratic. We would like to believe that directly changing culture and institutions would be the cause, not the consequence of economic development. but anyone who knows how societies work will understand that this causal inversion is very difficult. 


\section{References}

Bresser-Pereira, Luiz Carlos (2008) "The Dutch disease and its neutralization: a Ricardian approach", Brazilian Journal of Political Economy 28 (1): 47-71.

Bresser-Pereira, Luiz Carlos (2010) Globalization and Competition, New York: Cambridge University Press.

Bresser-Pereira, Luiz Carlos (2016) "Reflecting on new developmentalism and classical developmentalism", Review of Keynesian Economics 4 (3): 331-352. http://dx.doi.org/10.4337/roke.2016.03.07.

Bresser-Pereira, Luiz Carlos, José Luis Oreiro and Nelson Marconi (2016) Macroeconomia Desenvolvimentista. Rio de Janeiro: Campus/Elsevier.

Bresser-Pereira, Luiz Carlos and Paulo Gala (2008) "Foreign savings, insufficiency of demand, and low growth”, Journal of Post Keynesian Economics, 30 (3), Spring 2008: 315-334.

Corden, W. Max and J. Peter Neary (1982) "Booming sector and de-industrialization in a small open economy”, Economic Journal 92 (368): 825-848.

Corden, W. M. (1984) "Booming sector and Dutch disease economics: survey and consolidation", Oxford Economic Papers, 36 (3): 359-380.

Diamand, Marcelo (1972) "La estructura económica desequilibrada Argentina y el tipo de cambio", Desarrollo Económico 45 (12) abril-junho: 1-24.

Dvoskin, Ariel and Germaán David Feldman (2015) "Marcelo Diamand's contributions to economic theory thjrough the lens of the classical Keynesian approach: a formal presentation of unbalanced productive structures", Journal of Post Keynesian Economics 38 (2): 218-250.

Humphreys, Macartan, Jeffrey D. Sachs \& Joseph E. Stiglitz, eds. (2007) Escaping the Resource Curse, New York: Columbia University Press.

Karl, Terry Lynn (1997) The Paradox of Plenty, Berkeley: The University of California Press.

Karl, Terry Lynn (2007) "Ensuring fairness: The case for transparent fiscal social contracts", in Macartan Humphreys, Jeffrey D. Sachs and Joseph E. Stiglitz, eds (2007): 256-285.

Lederman, Daniel and William F. Maloney, eds. (2007) Natural Resources: Neither Curse nor Destiny, Washington and Stanford: World Bank and Stanford University Press.

Sachs, Jeffrey D. (2007) "How to handle the macroeconomics of oil wealth", in Macartan Humphreys, Jeffrey D. Sachs and Joseph E. Stiglitz, eds (2007):173-193.

Soros, George (2007) "Foreword" to Escaping the Resource Trap, in Macartan Humphreys, Jeffrey D. Sachs and Joseph E. Stiglitz, eds (2007): xi-Xv.

${ }^{1}$ This is something that simple historical research can probably demonstrate: if the domestic market was substantially more important than foreign markets for the American manufacturing industry prior to World War II, this hypothesis will be confirmed.

2 There is a sizable literature on new developmentalism. I cite here Bresser-Pereira (2008, 2010, 2016, 2017), and Bresser-Pereira, Marconi and Oreiro (2016). The last reference is a more complete version of the same book published originally in English by Routledge in 2014.

${ }^{3}$ In the same year another book on the theme, Natural Resource: Neither Curse nor Destiny, edited by Daniel Lederman and William F. Malonely, was published. The editors claim in their introduction that there is no natural resource curse or the "so called" Dutch disease. For them "several plausible indicators of the incidence of natural resource exports seem to have a rather positive than negative effect on 
subsequent economic growth. Put bluntly, there is no resource curse" (Lederman and Maloney 2007: 3 ; emphasis in original). I will not lose my time with such an approach.

${ }^{4}$ Interest rate "level" means the average real interest rate around which the central bank practices its monetary policy.

${ }^{5}$ It is usual to hear that the exchange rate became indeterminate because of the volume and unpredictability of capital flows. I agree that this poses difficulties, but this obstacle is not sufficient for giving up on creating a theory of the exchange rate. Second, in this model, capital flows are considered in one of the three habitual policies: growth with current-account deficits to be financed by capital flows. 